low-energy structure of 1 and 1,3/2-cyclohexanetriol generated by a molecular dynamics ${ }^{14}$ run from 0 to $300 \mathrm{~K}$ with 5 -fs step sizes, a path length of $105 \mathrm{ps}$, and the Amber force field, ${ }^{15}$ followed by minimizing random structures generated after multiple 4-ps intervals. The four hydrogen bonds indicated between 1 and the guest are those with interheteroatom distances of $2.9 \AA$ or less and hydrogen bonds angles greater than $160^{\circ} .16$ The molecular dynamics suggests that 1,3/2-cyclohexanetriol undergoes a reorganization to break one intramolecular hydrogen bond upon complexation as shown.

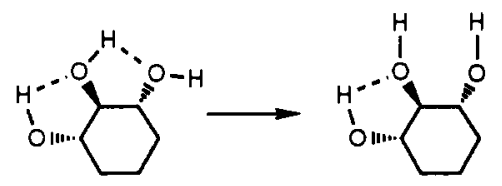

Binding constants (Table I) in chloroform were determined by ${ }^{1} \mathrm{H}$ NMR titrations of host into constant concentrations of cyclitols. Upfield chemical shifts of the guest $\mathrm{CHOH}$ resonances versus host concentration were fit to the typical binding algorithm, ${ }^{17}$ and downfield shifts of the $\mathrm{CHOH}$ resonances were observed. ${ }^{18}$ Host 1 binds stronger than $2,{ }^{19}$ indicating cooperativity between the $C_{2}$ symmetric halves of 1 . Within a series of guests (diols or triols), trans arrangements of hydroxyls yield larger binding constants. Furthermore, the binding constants are lower than predicted by comparison to complexes that passess four hydrogen bonds between relatively nonacidic donors and nonbasic acceptors. ${ }^{20}$

The selectivity is postulated to arise from competition between intramolecular hydrogen bonds in the guests and intermolecular hydrogen bonds with the host. Cis 1,2-hydroxyls form stronger intramolecular hydrogen bonds than trans 1,2 -hydroxyls. ${ }^{21}$ Infrared spectroscopy of the cyclitols in chloroform confirmed the intramolecular hydrogen bonds and indicated no guest oligomerization. In addition, the IR spectra of the diols confirmed the relative strength of cis versus trans intramolecular hydrogen bonds. Thus, trans hydroxyl stereochemistry leads to stronger complexation since the weaker intramolecular hydrogen bonds are broken. The intramolecular hydrogen bonds also depress the binding since the energy required to partially break them must be paid upon complexation. This competition will likely play a similar role in the complexation of saccharides with synthetic hosts in aprotic low dielectric solvents. Future saccharide receptors for such solvents will need to effectively compete with the intramolecular hydrogen bonds to achieve large association constants. The competition is another factor in addition to secondary interactions, ${ }^{22}$ electronic arguments, ${ }^{23}$ and strength of acid-base considerations, ${ }^{24}$ which should be considered in the interpretation of binding constants.

(14) Still, C. Macromodel Version 2.5, Columbia University, New York. (15) Weiner, S. J.; Kollman, P. A.; Case, D. A.; Singh, U. C.; Ghio, C.; Alagona, G. S.; Profeta, S.; Weiner, P. J. Am. Chem. Soc. 1984, 106, 765.

(16) One NH-O hydrogen bond is $140^{\circ}$ since the NH points to the O lone pair as in formamide-water dimer: Alagona, G.; Ghio, C.; Kollman, P. A. J. Am. Chem. Soc. 1983, 105, 5226-5230.

(17) Wilcox, C. S.; Cowart, M. D. Tetrahedron Lett. 1986, 27, 5563-5566. H. W. Whitlock, Jr., kindly provided the program. Sheridan, R. E.; Whitlock, H. W. J. Am. Chem. Soc. 1986, 108, 7120-7121, ref 8.

(18) Eyman, D. P.; Drago, R. S. J. Am. Chem. Soc. 1966, 88, 1617-1620. (19) Huang, C. Y.; Cabell, L. A.; Anslyn, E. V. Tetrahedron Lett. 1990, 31,7411 .

(20) Typically $K$ s vary in the $10^{3} \mathrm{M}^{-1}$ range: Bell, T. W.; Liu, J. J. Am Chem. Soc. 1988, 110, 3673-3674. Kelly, T. R.; Maguire, M. P. J. Am. Chem. Soc. 1987, 109, 6549-6551. Kelly, T. R.; Bilodeau, M. T.; Bridger, G. J.; Zhao, C. Tetrahedron Lett. 1989, 30, 2485-2488. Hegde, V.; Madhukar, P.; Madwa, J. D.; Thummel, R. P. J. Am. Chem. Soc. 1990, 112, 4549. Chang, S.-K.; Engen, D. V.; Fan, E.; Hamilton, A. D. J. Am. Chem Soc. 1991, 113, 7641-7645.

(21) Kuhn, L. P. J. Am. Chem. Soc. 1954, 76, 4324. Kuhn, L. P. J. Am. Chem. Soc. 1952, 74, 2492.

(22) Jorgenson, W. L.; Pranata, J. J. Am. Chem. Soc. 1990, 112, 2008-2010.

(23) Jeong, K. S.; Tjivikua, A.; Muehidorf, G.; Deslongchamps, M.; Famulok, M.; Rebek, J., Jr. J. Am. Chem. Soc, 1991, 113, 201-209. Jorgenson, W. L.; Severance, D. L. J. Am. Chem. Soc, 1991, 113, 209-216.

(24) Neder, K. M.; Whitlock, H. W., Jr. J. Am. Chem. Soc. 1990, 112, $9412-9414$.
Acknowledgment. Financial support came from the Texas Advanced Technology Program, and the N.S.F.-P.Y.I. program (E.V.A.). We also gratefully acknowledge synthetic advice from Drs. Phillip Magnus and James Whitesell of this department and Dr. Michael Petti of Rohm and Haas. In addition, we thank Dr. Eamon Healey for molecular dynamics advice.

Registry No. 1, 138722-49-3; 1 dimeric precursor, 138753-37-4; 3 , $42063-01-4 ; 3$ hydroxymethylene derivative, 138722-50-6; 4, 138722$51-7 ; 5,138722-53-9 ; 5$ phenylmethylene precursor, 138722-52-8; 58 (ethoxycarbonylmethylene) derivative, 138722-55-1; 6, 138722-54-0; 1-(trimethylsilyl)pyrrolidine, 15097-49-1; cycloheptanone, 502-42-1; cis-1,2-cyclohexanediol, 1792-81-0; trans-1,2-cyclohexanediol, 1460-57-7; $(1 \alpha, 2 \beta, 3 \alpha)$-1,2,3-cyclohexanetriol, 2630-65-1; (1 $\alpha, 2 \alpha, 3 \beta)-1,2,3$-cyclohexanetriol, 10515-21-6; (1 $\alpha, 2 \alpha, 3 \alpha)$-1,2,3-cyclohexanetriol, 2630-64-0.

\section{Formation of Gaseous $\pi$ and Ion-Neutral Complexes As Probed by Interannular tert-Butyl Cation Transfer in Protonated tert-Butyl-Substituted Diphenylalkanes ${ }^{\dagger}$}

\author{
Dietmar Kuck ${ }^{*, 1}$ and Carsten Matthias \\ Fakultät für Chemie, Universität Bielefeld \\ Universitätsstrasse 25, D-4800 Bielefeld 1, FRG
}

Received October 8, 1991

The role of $\pi$ and $\sigma$ complexes as reactive intermediates in electrophilic aromatic substitution reactions has become common textbook knowledge..$^{2-4}$ However, detailed information on the structure, reactivity, and energetics is only available for $\sigma$ complexes, both in solution ${ }^{5}$ and in the gas phase. ${ }^{6}$ In contrast, the occurrence and properties of $\pi$ complexes, at least in the gas phase, ${ }^{4}$ are much less clear.

The existence of gaseous $\pi$ complexes along with the corresponding $\sigma$ complexes has been shown in some cases by utilizing sophisticated mass spectrometric techniques. ${ }^{7-9}$ Moreover, the unimolecular formation of noncovalent, i.e., purely electrostatically bound, ion-neutral complexes during the fragmentation of gaseous organic ions has been studied in greater detail. ${ }^{10-17}$ For protonated

\footnotetext{
${ }^{\dagger}$ Dedicated to Dr. Curt Brunnêe, Bremen/Ritterhude.
}

(1) (a) Recipient of the 1988 Mattauch-Herzog Award for Mass Spectrometry. (b) This paper was presented at the 12th International Mass Spectrometry Conference, Amsterdam, August 25-30, 1991.

(2) March, J. Advanced Organic Chemistry, Reactions, Mechanisms, and Structure, 3rd ed; John Wiley \& Sons: New York, 1985; Chapter 11.

(3) Walter, W. Lehrbuch der Organischen Chemie/Beyer; Walter, 22nd ed.; S. Hirzel Verlag: Stuttgart, 1991; Chapter S.

(4) Vogel, P. Carbocation Chemistry; Elsevier: Amsterdam, 1985.

(5) (a) Taylor, R. Electrophilic Aromatic Substitution; John Wiley \& Sons: Chichester, England, 1990. (b) Olah, G. A.; Surya Prakash, G. K.; Sommer, J. Superacids; John Wiley \& Sons: New York, 1985. (c) Ahlberg, P.; Jonsäll, G.; Engdah], C. Adv. Phys. Org. Chem. 1983, 19, 223-379. (c) Koptyug, V. A. Top. Curr. Chem. 1984, 122, 1-245. (d) Shubin, V. G. Top Curr. Chem. 1984, 116/117, 267-341. (e) Brouwer, D. M.; Mackor, E. L.; MacLean, C. In Carbonium Ions; Olah, G. A., Schleyer, P. v. R., Eds; Wiley: New York, 1970; Vol. 2, Chapter 20.

(6) Kuck, D. Mass Spectrom. Rev. 1990, 9, 583-630.

(7) Holman, R. W.; Gross, M. L. J. Am. Chem. Soc. 1989, 111, $3560-3565$.

(8) Audier, H. E.; Monteiro, C.; Mourgues, P.; Berthomieu, D. Org. Mass Spectrom. 1990, 25, 245-246.

(9) The formation of $\pi$ complexes in the protonolysis of gaseous alkylbenzenes has been invoked in earlier CI studies: (a) Herman, J. A.; Harrison, A. G. Org. Mass Spectrom. 1981, 16, 423-427. (b) Audier, H. E.; Monteiro, C.; Robin, D. New J. Chem. 1989, 13,621-624. (c) Berthomieu, D.; Audier H. E.; Denhez, J.-P.; Monteiro, C.; Mourgues, P. Org. Mass Spectrom. 1991, $26,271-275$.

(10) Review: McAdoo, D. J. Mass Spectrom. Rev. 1988, 7, 363-393. (b) For selected recent papers on positive ion-neutral complexes, see refs 11-16.

(11) (a) Ahmed, M. S.; Hudson, C. E.; Traeger, J. C.; Giam, C. S.; McAdoo, D. J. J. Am. Chem. Soc. 1990, 112, 6443-6445. (b) Traeger, J. C.; Hudson, C. E.; McAdoo, D. J. Submitted for publication. 
Scheme I

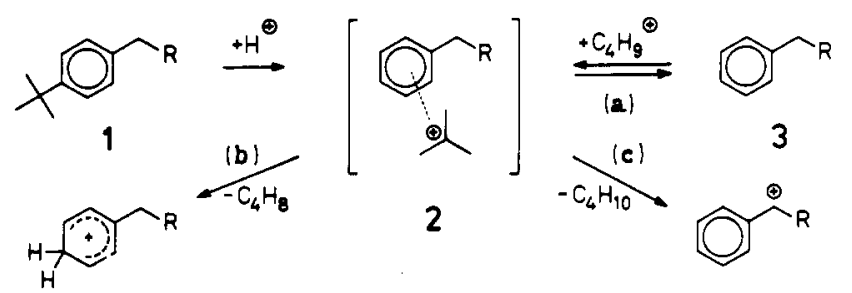

Scheme II

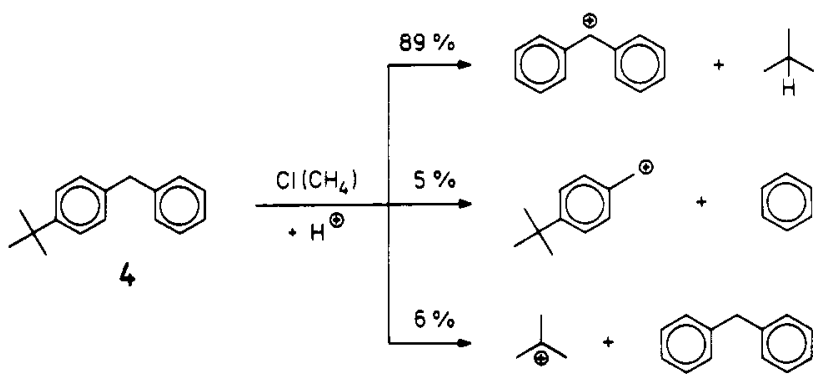

alkylbenzenes, representing prototype intermediates in electrophilic aromatic substitution, the existence of ion-molecule (non- $\pi$-type) complexes has been inferred in a limited number of cases. ${ }^{6,8,9 c, 18}$ In this preliminary report, we present the first evidence for the mobility of an alkyl ion within $\pi$ complexes of $\alpha, \omega$-diphenylalkanes.

Recently, Audier et al. ${ }^{8}$ reported that protonation of tert-butyl-substituted ethylbenzenes (e.g., $1, \mathrm{R}=\mathrm{CH}_{3}$ ) and related hydrocarbons in the chemical ionization (CI) source plasma gives rise to the loss of isobutane (Scheme I, path c) by highly regioselective hydride abstraction from the benzylic methylene group(s), and they suggested the formation of the corresponding $\pi$ complexes (e.g., $2, \mathrm{R}=\mathrm{CH}_{3}$ ). In the course of our work on gaseous alkylbenzenium ions, ${ }^{6}$ we had found that the $[\mathrm{M}+\text { alkyl }]^{+}$ adduct ions of $\alpha, \omega$-diphenylalkanes $3(\mathrm{R}=\omega$-phenylalkyl) formed in the CI plasma also underwent loss of the corresponding alkane (path c) along with the more frequently occurring elimination of alkene (path $b$ ). Therefore, we have searched for more compelling evidence for the formation of $\pi$ complexes by studying the fragmentation of protonated tert-butyl-substituted $\alpha, \omega$-diphenylalkanes. In these systems, the formation of complexes should be clearly indicated by hydride abstraction from both the $\alpha$ and the $\omega$ positions.

(4-tert-Butylphenyl)phenylmethane (4) and 1-(4-tert-butylphenyl)-3-phenylpropane (5) (as well as several deuterium-labeled analogues of 5) were synthesized, ${ }^{19-21}$ and the mass-analyzed ion

(12) (a) Longevialle, P.; Botter, R. J. Chem. Soc., Chem. Commun. 1980, 823-825. (b) Longevialle, P.; Bouchoux, G.; Hoppilliard, Y. Org. Mass Spectrom. 1990, 25, 527-536.

(13) (a) Morton, T. H. Tetrahedron 1982, 38, 3195-3243. (b) Morton, T. H. J. Am. Chem. Soc. 1980, 102, 1596-1602. (c) Kondrat, R. W;; Morton, T. H. Org. Mass Spectrom. 1991, 26, 410-415.

(14) (a) Bowen, R. D.; Williams, D. H. J. Am. Chem. Soc. 1980, 102 2752-2756. (b) Bowen, R. D.; Maccoll, A. J. Chem. Soc., Perkin Trans. 2 $1990,147-155$.

(15) (a) Bäther, W.; Grützmacher, H.-F. Int. J. Mass Spectrom. Ion Proc. 1985, 64, 193-212. (b) Filges, U.; Grützmacher, H.-F. Org. Mass Spectrom 1986, 21, 673-680. (c) Filges, U.; Grützmacher, H.-F. Int. J. Mass Spectrom Ion Proc. 1988, 93, 111-133. (d) Grützmacher, H.-F.; Thielking, G.; Wittneben, D.; Eikenberg, D. Int. J. Mass Spectrom. Ion Proc. 1990, 98, 259-268.

(16) (a) Hammerum, S.; Audier, H. E. J. Chem. Soc., Chem. Commun. 1988, 860-861. (b) George, H.; Holmes, J. L. Org. Mass Spectrom. 1990, 25, 605-608.

(17) The formation of ion-neutral complexes has been suggested to explain a particularly complex triple hydrogen rearrangement reaction: Kuck, D. Filges, U. Org. Mass Spectrom. 1988, 23, 643-653.

(18) Kuck, D. Int. J. Mass Spectrom. Ion Phys. 1983, 47, 499-502.

(19) 4 was obtained from the corresponding benzhydrol by hydrogenolysis with $\mathrm{Pd} / \mathrm{C}$ in ethanol at $3 \mathrm{bar} / \mathrm{room}$ temperature as a colorless oil: bp 105 ${ }^{\circ} \mathrm{C} / 0.07 \mathrm{mbar}$ (Kugelrohr); ${ }^{1} \mathrm{H}$ NMR (60 MHz, CDCl $\left.{ }_{3}\right) 87.00-7.45$ (m, 9 H), $3.90(\mathrm{~s}, 2 \mathrm{H}), 1.31(\mathrm{~s}, 9 \mathrm{H})$; MS (EI, $70 \mathrm{eV}) \mathrm{m} / \mathrm{z} 224\left(21, \mathrm{M}^{\circ+}\right), 209$ (68), $208(100), 181(14), 167(23), 166(13), 165(31), 152(12), 115(19), 105$ (13), $104(19), 92(22), 91(100), 90(26), 89(25)$.
Scheme III

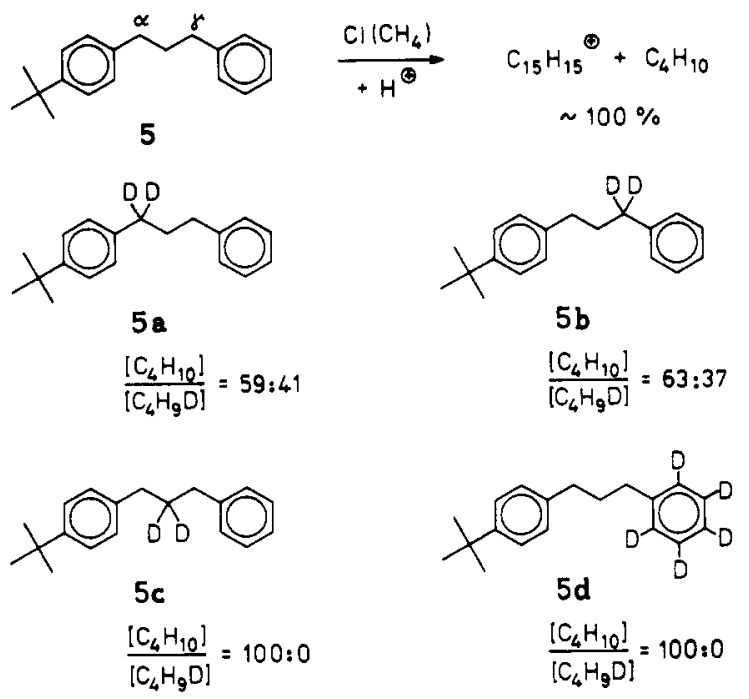

kinetic energy (MIKE) spectra ${ }^{22}$ of their $[\mathrm{M}+\mathrm{H}]^{+}$ions were measured. ${ }^{23}$ Metastable ions $[4+\mathrm{H}]^{+}$lose isobutane as the predominant fragmentation (Scheme II). Simple heterolysis of the $\mathrm{C}^{4}-\mathrm{C}\left(\mathrm{CH}_{3}\right)_{3}$ (path a) and $\mathrm{C}^{\mathrm{L}}-\mathrm{CH}_{2} \mathrm{C}_{6} \mathrm{H}_{5}$ bonds represent minor processes. This is in line with the favorable hydride abstraction by the tert-butyl ion from the benzylic $\mathrm{C}-\mathrm{H}$ bonds in the diphenylmethane partner of an ion-molecule complex $2\left(\mathrm{R}=\mathrm{C}_{6} \mathrm{H}_{5}\right)$ resulting from ipso protonation in $[4+\mathrm{H}]^{+}$.

Metastable ions $[5+\mathrm{H}]^{+}$undergo exclusive loss of isobutane (Scheme III). Thus, in contrast to protonated tert-butylbenzene ${ }^{9 a, 24}$ and ions $[4+\mathrm{H}]^{+}$, free $\mathrm{C}_{4} \mathrm{H}_{9}{ }^{+}$ions (path a) are not formed. The MIKE spectra of the $\left[2,2-{ }^{2} \mathrm{H}_{2}\right]-$ and $\left[\right.$ ring- $\left.{ }^{2} \mathrm{H}_{5}\right]-$ labeled analogues $[\mathbf{5 c}+\mathbf{H}]^{+}$and $[\mathbf{5 d}+\mathbf{H}]^{+}$exhibit complete retention of the label; hence, isobutane loss does not involve a hydride from the homobenzylic position or from the aromatic rings. The $\left[1,1-{ }^{2} \mathrm{H}_{2}\right]-$ and $\left[3,3-{ }^{2} \mathrm{H}_{2}\right]$-labeled ions $[5 \mathrm{a}+\mathrm{H}]^{+}$and $[5 \mathbf{b}+$ $\mathrm{H}]^{+}$, however, both expel $\mathrm{C}_{4} \mathrm{H}_{10}$ and $\mathrm{C}_{4} \mathrm{H}_{9} \mathrm{D}$, and the abundance ratios of the isotopomers are very close (Scheme III). Clearly, within experimental error, the hydride abstraction occurs with the same probability at the formally adjacent $(\alpha)$ and remote $(\gamma)$ benzylic methylene groups, and the kinetic isotope effect

(20) Compounds 5 and $5 a-d$ were synthesized via the corresponding 4- and $4^{\prime}$-tert-butylchalcones and -dihydrochalcones. The latter were reduced with $\mathrm{H}_{2} / \mathrm{Pd} / \mathrm{C}$ in acetic acid or $\mathrm{D}_{2} / \mathrm{Pd} / \mathrm{C}$ in $\left[\mathrm{O}^{2} \mathrm{H}\right]$ acetic acid, respectively, in a Parr hydrogenation apparatus at $5 \mathrm{bar} / \mathrm{room}$ temperature. ${ }^{21}$ Compound 5 was obtained in near-quantitative yield as a colorless oil: bp $120^{\circ} \mathrm{C} / 0.06 \mathrm{mbar}$ (Kugelrohr); ${ }^{1} \mathrm{H}$ NMR $\left(300 \mathrm{MHz}, \mathrm{CDCl}_{3}\right) \delta 7.11-7.32(\mathrm{~m}, 9 \mathrm{H}), 2.66\left(\mathrm{t},{ }^{3} \mathrm{~J}\right.$ $=7.77 \mathrm{~Hz}, 2 \mathrm{H}), 2.63\left(\mathrm{t},{ }^{3} J=7.82 \mathrm{~Hz}, 2 \mathrm{H}\right), 1.96\left(\mathrm{q},{ }^{3} J=7.8 \mathrm{~Hz}, 2 \mathrm{H}\right)$, $1.31(\mathrm{~s}, 9 \mathrm{H})$; MS (EI, $70 \mathrm{eV}) \mathrm{m} / 2252\left(33, \mathrm{M}^{+}\right), 237(100), 147(9), 131$ (18), $117(26), 105(22), 91$ (78). [2,2- $\left.{ }^{2} \mathrm{H}_{2}\right]-3$-(4-tert-Butylphenyl)-1phenylpropan-1-one was prepared by $\mathrm{H} / \mathrm{D}$ exchange in dioxane $/ \mathrm{D}_{2} \mathrm{O} / \mathrm{NEt}_{3}$ to give, after reduction, $5 \mathrm{c}$ with $85 \% d_{2}$ (isotope content $91.7 \% d$ ); likewise, the $1-\left(\left[{ }^{2} \mathrm{H}_{5}\right]\right.$ phenyl) phenone gave $5 \mathrm{~d}$ with $89 \% d_{5}(97.5 \% d)$. For $5 \mathrm{a}$, surprisingly, repeated runs gave only low isotopic purity and site-specificity $(7 \%$ $\left.d_{1}, 27 \% d_{2}, 39 \% d_{3}, 23 \% d_{4}, 3 \% d_{5} ; 141 \% d\right)$. By contrast, the reduction of 5 b occurred relatively cleanly $\left(16 \% d_{1}, 72 \% d_{2}, 9 \% d_{3}, 2 \% d_{4} ; 96.6 \% d\right)$. Note that the MIKES technique allows the selection, in this case, of the $[\mathrm{M}+\mathrm{H}]^{+}$ isotopomer of interest, except for those isobaric ions containing natural ${ }^{13} \mathrm{C}$. Thus, for $\left[5 \mathrm{a}+\mathrm{H}^{+}\right.$, an increased experimental error $( \pm 5 \% \Sigma)$ has to be taken into account.

(21) (a) Ofosu-Asante, K.; Stock, L. M. J. Org. Chem. 1987, 52, 2938-2939. (b) According to our experience, $D_{2}$ pressures as high as 4-5 bar (in contrast to ref 21a) are required to achieve the reduction of phenones without significant loss of the deuterium label.

(22) (a) Chapman, J. R. Practical Organic Mass Spectrometry; John Wiley \& Sons: Chichester, England, 1985; Chapter 6. (b) Cooks, R. G.; Beynon, J. H.; Caprioli, R. M.; Lester, G. R. Metastable Ions; Elsevier: Amsterdam, 1973 .

(23) A ZAB-2F double-focussing mass spectrometer (VG Analytical, Manchester, UK) with the magnetic sector preceding the electrostatic one was utilized under standard CI conditions (Kuck, D.; Thölmann, D.; Grützmacher, H.-F. J. Chem. Soc., Perkin Trans. 2 1990, 251-256), with methane (Matheson, $>99.95 \%$ ) as the reagent gas.

(24) Cacace, F.; Crestoni, M. E.; de Petris, G.; Fornarini, S.; Grandinetti, F. Can. J. Chem. 1988, 66, 3099-3107. 
Scheme IV

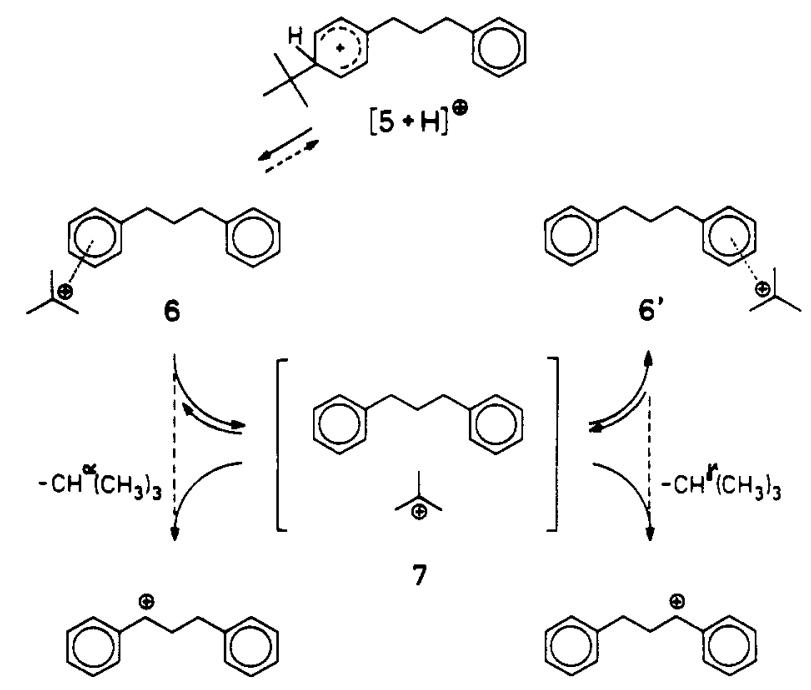

$\left(k_{\mathrm{H}} / k_{\mathrm{D}}\right)$ observed is the same as that reported for simpler alkylbenzenium ions. 8,25

The overall course of the reaction is illustrated in Scheme IV. Besides interannular proton transfer, which according to our previous studies should operate in $[5+\mathrm{H}]^{+}$as well, ${ }^{6,26}$ a degenerate interannular transalkylation equilibrium may occur between the primarily formed $\pi$ complex 6 and its "tautomer", 6 '. In addition, however, an ion-neutral complex (7) appears to be involved as the central intermediate since the aliphatic chain of $[5+\mathrm{H}]^{+}$does not allow for a "direct" tert-butyl ion transfer via a geometry akin to an $\mathrm{S}_{\mathrm{N}} 2$ transition state, viz., [arene... $\mathrm{C}\left(\mathrm{CH}_{3}\right)_{3} \ldots$ arene] ${ }^{+}{ }^{6}$ Such a transition state has been suggested by Kebarle et al. ${ }^{27}$ for the intermolecular transalkylation between tert-butylbenzene and toluene under high-pressure CI conditions. ${ }^{27,28}$ We therefore believe that complex 7, rather than 6 and $6^{\prime}$, is the actual intermediate in which the hydride abstraction step takes place. Hence, the results presented here corroborate the possibility that intermolecular gas-phase transalkylation reactions may take place via ternary complexes, ${ }^{29}$ viz., [arene $\mathrm{C}_{4} \mathrm{H}_{9}{ }^{+}$arene'], as truly "disolvated ions".6,9a,11b,18

We hope that further investigations into complex-mediated alkyl ion migrations at the "backbone" of larger aryl-substituted alkanes will add further interesting facets to our understanding of the behavior of gas-phase $\pi$ and ion-molecule complexes.

Acknowledgment. This work was supported by the Forschungsprojekt 2194/26, Universität Bielefeld. Persistent fruitful discussions with Professor Hans-F. Grützmacher and experimental contributions by Matthias Jöckel in an early stage of this work are gratefully acknowledged. We thank Dr. David J. McAdoo for a preprint (ref $11 \mathrm{~b}$ ).

Registry No. 4, 16251-99-3; 5, 138722-44-8; 5a, 138722-42-6; 5b, 138722-43-7; 5c, 138753-36-3; 5d, 138722-45-9; $\mathrm{C}_{4} \mathrm{H}_{9}{ }^{+}, 14804-25-2$; benzhydrol, 91-01-0; 3-(4-tert-butylphenyl)-1-phenylpropanone, 138722-46-0; [2,2- $\left.{ }^{2} \mathrm{H}_{2}\right]$-3-(4-tert-butylphenyl)-1-phenylpropan-1-one, 138722-47-1; 3-(4-tert-butylphenyl)-1- $\left[{ }^{2} \mathrm{H}_{5}\right]$ phenylpropan-1-one, $138722-48-2$.

(25) With $[\alpha]$ and $[\gamma]$ representing the fractional attack of the tert-butyl ion at the $\alpha$ and $\gamma$ positions of ions $[5+\mathrm{H}]^{+}$and with $k_{\mathrm{H}} / k_{\mathrm{D}} \equiv$ $\left[\mathrm{C}_{4} \mathrm{H}_{2} \mathrm{H}^{i}\right] /\left[\mathrm{C}_{4} \mathrm{H}_{9} \mathrm{D}^{i}\right](\mathrm{i}=\alpha$ or $\gamma$ ), the observed abundance ratios expressed as $\left[\mathrm{C}_{4} \mathrm{H}_{9} \mathrm{H}^{\gamma}\right] /\left[\mathrm{C}_{4} \mathrm{H}_{9} \mathrm{D}^{\alpha}\right]=([\gamma] /[\alpha])\left(k_{\mathrm{H}} / k_{\mathrm{D}}\right)$ for $[5 \mathrm{a}+\mathrm{H}]^{+}$and as $\left[\mathrm{C}_{4} \mathrm{H}_{9} \mathrm{H}^{\alpha}\right] /\left[\mathrm{C}_{4} \mathrm{H}_{9} \mathrm{D}^{\gamma}\right]=([\alpha] /[\gamma])\left(k_{\mathrm{H}} / k_{\mathrm{D}}\right)$ for $\left[5 \mathrm{~b}+\mathrm{H}^{+},[\alpha]=0.52,[\gamma]=\right.$ 0.48 , and $k_{\mathrm{H}} / k_{\mathrm{D}}=1.57$.

(26) (a) Bäther, W.; Kuck, D.; Grützmacher, H.-F. Org. Mass Spectrom. 1985, 20, 589-591. (b) Kuck, D. Unpublished results.

(27) Sen Sharma, D. K.: Ikuta, S.; Kebarle, P. Can. J. Chem. 1982, 60 , 2325-2331.

(28) Cacace, F.; Ciranni, G. J. Am. Chem. Soc. 1986, 108, 887-890.

(29) Monteiro, C.; Audier, H. E.; Mourgues, P.; Berthomieu, D. Rapid Commun. Mass Spectrom. 1990, 4, 92-95.
Efficient Catalytic Cleavage of RNA by Lanthanide(III) Macrocyclic Complexes: Toward Synthetic Nucleases for in Vivo Applications

Janet R. Morrow, ${ }^{*}$ Lisa A. Buttrey, Valerie M. Shelton, and Kristin A. Berback

\author{
Chemistry Department \\ State University of New York at Buffalo \\ Buffalo, New York 14214 \\ Received September 16, 1991
}

Reagents that cleave RNA by promoting transesterification of the phosphate diester linkage of RNA have been the subject of several recent studies. ${ }^{1-10}$ Cleavage of RNA by transesterification has many advantages over oxidative cleavage, including the possibility of religation of fragments, the high degree of selectivity for cleavage of RNA over DNA, ${ }^{11}$ and the elimination of diffusible oxygen radicals that are often produced in metal-ion-promoted oxidative cleavage of nucleic acids. The latter two are important advantages because the use of metal complexes that promote oxidative cleavage of nucleic acids may result in destruction of the ligand or tethered recognition molecule. ${ }^{12}$ One of the most tantalizing applications of RNA transesterification catalysts is the possibility of forming more potent antisense oligonucleotides by attachment of a catalytic cleaving group. ${ }^{13}$ An antisense oligonucleotide with an attached cleaving group able to participate in the catalytic destruction (several copies of mRNA per antisense oligonucleotide) of selected sequences of RNA might truly be effective in the inhibition of gene expression. To date, however, many reagents used to cleave RNA are employed in large excess $^{1-5}$ and catalytic turnover has not been demonstrated. We report here the first example of a metal complex $\left(\operatorname{Eu}\left(L^{1}\right)^{3+}\right)$ that shows catalytic behavior in RNA transesterification at $37^{\circ} \mathrm{C}$ and neutral $\mathrm{pH}$. In addition, several lanthanide(III) complexes of $\mathrm{L}^{1}$

(1) Barbier, B.; Brack, A. J. Am. Chem. Soc. 1988, 110, 6880-6882.

(2) Breslow, R.; Huang, D.-L.; Anslyn, E. Proc. Natl. Acad. Sci. U.S.A. 1989, 86, 1746-1750.

(3) (a) Breslow, R.; Huang, D.-L. J. Am. Chem. Soc. 1990, 112, 9621-9623. (b) Anslyn, E; Breslow, R. J. Am. Chem. Soc. 1989, 111 , 4473-4482. (c) Breslow, R.; LaBelle, M. J. Am. Chem. Soc. 1986, 108 2655-2659.

(4) Matsumoto, Y,; Komiyama, M. J. Chem. Soc., Chem. Commun. 1990, $1050-1051$

(5) Yoshinari, K.; Yamazaki, K.; Komiyama, M. J. Am. Chem. Soc. 1991, 113, 5899-5901.

(6) Stern, M. K.; Bashkin, J. K.; Sall, E. D. J. Am. Chem. Soc. 1990, 112, 5357-5359.

(7) Modak, A. S.; Gard, J. K.; Merriman, M. C.; Winkeler, K. A.; Bashkin, J. K.; Stern, M. K. J. Am. Chem. Soc. 1991, 113, 283-291.

(8) Shelton, V. M.; Morrow, J. R. Inorg. Chem. 1991, 30, 4295-4299.

(9) Less recent literature contains reports of metal salts that cleave RNA (a) Butzow, J. J.; Eichhorn, G. L. Biopolymers 1965, 3, 95-107. (b) Ikenaga, H.; Inoue, Y. Biochemistry 1974, 13, 577-582. (c) Eichhorn, G. L.; Tarien, E.; Butzow, J. J. Biochemistry 1971, 10, 2014-2019. (d) Butzow, J. J.; Eichhorn, G. L. Ibid. 1971, 10, 2019-2024. (e) Farkas, W. R. Biochim. Biophys. Acta 1967, I55, 401-409. (f) Eichhorn, G. L.; Butzow, J. J. Biopolymers 1965, 3, 79-94. (g) Baumann, E.; Trapman, H.; Fischler, F. Biochem. Z. 1954, 328, 89-96. (h) Dimroth, K.; Witzel, H.; Hulsen, W.; Mirbach, H. Ann. Chem. 1959, 620, 94-108.

(10) Several transfer RNAs as well as self-cleaving RNAs cleave readily in the presence of metal ions at $37^{\circ} \mathrm{C}$; a metal-ion-binding pocket probably facilitates this process: (a) Brown, R. S.; Hingerty, B. E.; Dewan, J. C.; Klug, A. Nature 1983, 303, 543-546. (b) Brown, R. S.; Dewan, J. C.; Klug, A Biochemistry 1985, 24, 4785-4801. (c) Werner, C.; Krebs, B.; Keith, G Dirheimer, G. Biochim. Biophys. Acta 1976, 432, 161-175. (d) Prody, G. A.; Bakos, J. T.; Buzayan, J. M.; Schneider, I. R.; Bruening, G. Science 1986, 231, 1577-1580. (e) Behlen, L. S.; Sampson, J. R.; DiRenzo, A. B.; Uhlenbeck, O. C. Biochemistry 1990, 29, 2515-2523. (f) Uhlenbeck, O. C. Nature 1987, 328, 595-600. (g) Rordorf, B. F.; Kearns, D. R. Biopolymers 1976 1491-1504. (h) Dange, V.; Van Atta, R. B.; Hecht, S. M. Science 1990, 248, 585-588.

(11) Butzow, J. J.; Eichhorn, G. L. Nature 1975, 254, 358-359.

(12) (a) Chu, B. C. F.; Orgel, L. E. Proc. Natl. Acad. Sci. U.S.A. 1985, 82, 963-967. (b) Le Doan, T.; Perrouault, L.; Helene, C. Biochemistry 1986, $25,6736-6739$.

(13) Stein, C. A.; Cohen, J. S. Cancer Res. 1988, 48, 2659-2688. 